\title{
The Response of G7 Real Exchange Rates to Oil Price Shocks
}

\author{
Moayad H. Al Rasasi ${ }^{1}$ \\ ${ }^{1}$ Economic Research Department, Saudi Arabian Monetary Authority, Riyadh, Saudi Arabia \\ Correspondence: Moayad H. Al Rasasi, Economic Research Department, Saudi Arabian Monetary Authority, \\ Riyadh, Saudi Arabia. Tel: 966-11-463-3000. E-mail: malrasasi@sama.gov.sa
}

Received: February 3, 2018

Accepted: March 18, 2018

Online Published: March 20, 2018

doi:10.5539/ijef.v10n4p191

URL: https://doi.org/10.5539/ijef.v10n4p191

\begin{abstract}
This paper evaluates the response of G7 real exchange rates to oil supply and demand shocks developed by Kilian (2009). We find evidence suggesting that oil shocks are associated with the appreciation (depreciation) of real exchange rates for oil exporting (importing) countries. Further evidence, based on the analysis of forecast error variance decomposition, indicates that oil-specific demand shocks are the main contributor to variation in real exchange rates, whereas oil supply shocks contribute the least. Finally, regarding the role of monetary policy in responding to oil and exchange rate shocks, we find evidence showing monetary policy reacts only to oil-specific demand and aggregate demand shocks in three countries, whereas monetary policy responds to real exchange rate fluctuations in four countries.
\end{abstract}

Keywords: real exchange rate, G7 countries, oil shocks, monetary policy

\section{Introduction}

In recent years, both oil prices and exchange rates have experienced sharp fluctuations, as shown in Figure 1. Swings in oil prices are transmitted to financial markets and various economic activities through exchange rates. For example, exchange rate volatility affects stock markets (Basher et al., 2012; Bello, 2013), oil \& currency portfolios (Beine, 2006), terms of trade (Amano \& Norden, 1998; Backus \& Crucini, 2000), currency \& energy options (Salmon \& Schleicher, 2007), labor markets (Burgess \& Knetter, 1998), economic growth (Hausmann et al., 2005), investments (Harchaoui et al., 2005), and energy \& currency risk management (Marimoutou et al., 2009; Sadegui \& Shavvalpour, 2006).

Based on economic theory, the terms of trade are the main channel in which changes in oil prices are transmitted to exchange rates. Cashin et al. (2004) developed a model for two sectors of tradable and non-tradable goods. According to their model, each sector uses both inputs of tradable (oil) and non-tradable (labor) goods. The tradable sector's output prices are fixed in international markets, and real exchange rates are linked to the non-tradable sector's output prices. When oil prices go up, labor prices fall, due to competitiveness of the tradable sector. If the non-tradable sector depends more heavily on imported crude oil than the tradable sector, then the output price of the non-tradable sector increases, and the real exchange rate rises as well. The opposite results are expected when the non-tradable sector is less dependent on imported crude oil than the tradable sector.

Several studies (Sadorsky, 2000; Akram, 2004; Chen \& Chen, 2007; Narayan et al., 2008; and Uddin et al., 2014) support the notion of oil prices being able to explain exchange rates via the terms of trade channel. However, it is important to emphasize that prevailing studies tend to interpret changes in oil prices as exogenous supply shocks, due to exogenous factors, such as wars or political instability in the Middle East or other oil-producing countries, which lead to oil supply disruption. Conversely, Kilian (2009) provides an alternative view. 


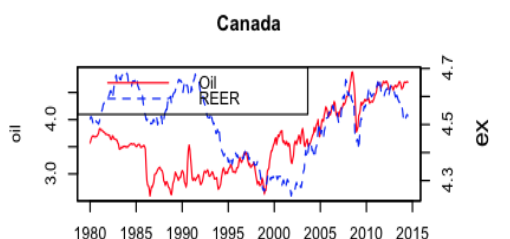

Time

Italy

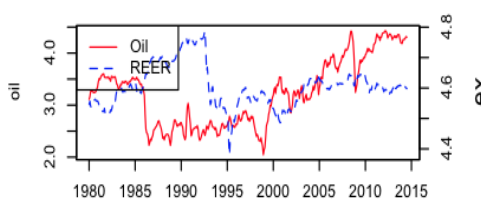

Time

United States

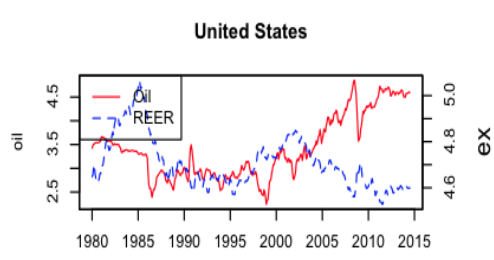

Time
France

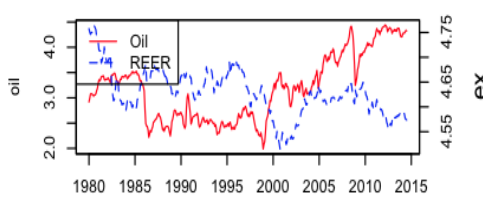

Time

Japan

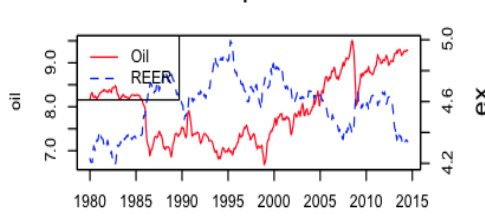

Time
Germany

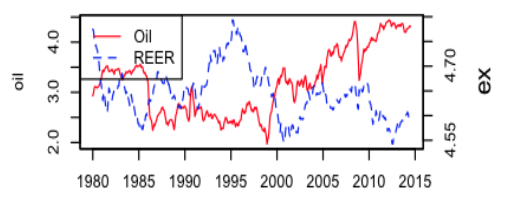

Time

United Kingdom

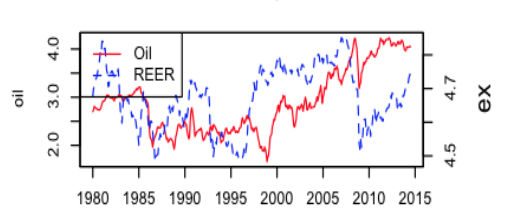

Time

Figure 1. Oil Prices and G7 real effective exchange rate movements

He argues that the impact of oil shocks varies, depending on the underlying source of oil shocks. In addition, Kilian states that the common belief represented in the literature before 2009-that changes in oil prices were mainly driven by disruptions in oil supply, and that those supply shocks led to major recessions in the US - is no longer valid. Consequently, Kilian (2009) distinguishes between oil supply shocks, aggregate demand shocks, and oil-specific demand shocks, based on the underlying source that causes oil prices to surge. He points out that aggregate demand shocks are driven by a booming world economy, whereas oil-specific demand shocks are driven by precautionary demand for oil in the crude oil market due to concerns about future oil shortfalls. Kilian (2009) also indicates that oil supply shocks result from oil production shortfalls in oil-producing countries.

The seminal work of Kilian (2009) differentiating between oil supply and demand shocks has led researchers to investigate the differential effects of oil shocks using various macro and financial activities, for instance, Kilian's measures as applied to the crude oil market and US macroeconomic aggregates (Kilian, 2009), external balances (Kilian et al., 2009), the US stock market (Kilian \& Park, 2009), and US monetary policy (Kilian \& Lewis, 2011). These studies show that the economic and financial variables respond differently to oil supply and demand shocks. Hence, since identifying the response of exchange rates to oil supply and demand shocks has not yet been examined, this motivates us to examine the differential effects of oil supply and demand shocks on the real exchange rates of G7 countries. Through this paper, we contribute to the literature in two ways. First, we investigate how G7 real exchange rates respond to oil supply and demand shocks. Second, we re-assess the role of monetary policy in reacting to real exchange rate shocks as well as oil shocks.

The remainder of the paper is organized as follows: Section 2 reviews existing literature while Section 3 describes the dataset employed. Section 4 outlines the empirical methodology alongside the empirical results. Section 5 discusses the implications of the results, and Section 6 contains the conclusion.

\section{Literature Review}

Numerous empirical studies not only consider the terms of trade as the essential channel transmitting changes in oil prices into the exchange rate to investigate the effects of oil prices on the exchange rate, but also confirm the influential role of oil price shocks on exchange rates. It is also essential to indicate that the obtainable literature examining the oil-exchange rate relationship attributes changes in oil prices to oil supply disruption.

For instance, Amano and Norden (1998) use oil prices as a proxy for the terms of trade to examine the consequences of oil price increases on the movements of the real effective exchange rates of Germany, Japan, and the US. Their results reveal that higher oil prices lead to the depreciation of the German and Japanese real 
exchange rates, whereas higher oil prices cause the US real exchange rate to appreciate. Sadorsky (2000) examines whether various energy prices impact the trade-weighted US exchange rate and documents evidence indicating the existence of a negative relationship between energy prices and the USD exchange rate. Likewise, Yousefi and Wirjanto (2004) analyze the impact of oil prices on exchange rates for OPEC countries via the GMM methodology and confirm the negative relationship between oil prices and exchange rates. Using panel cointegration analysis, Chen and Chen (2007) also examine the effects of oil prices on the movements of bilateral real exchange rates of G7 countries, and document that changes in oil prices result in the depreciation of G7 real exchange rates.

Coudert et al. (2007) find empirical evidence supporting the existence of a stable long-run relationship between the USD real effective exchange rate and oil prices. They report that higher oil prices lead to the appreciation of the USD real effective exchange rate. Huang and Guo (2007) also show that higher oil prices lead to the appreciation of the Chinese real exchange rate against the US dollar in the long run. Narayan et al. (2008) also find evidence based on GARCH and E-GARCH models supporting the negative relationship between oil prices and the US dollar exchange rate against the currency of the Fiji Islands. Based on the autoregressive distributed lag (ARDL) model, Jahan-Parvar and Mohammadi (2008) show that oil price increases lead to the depreciation of the US dollar against the currencies of 14 oil-exporting countries. However, in a later paper, Mohammadi and Jahan-Parvar (2012) re-examine the validity of the Dutch disease hypothesis using threshold and momentum-threshold models. Their findings show that the Dutch disease hypothesis is valid for only three out of 13 oil-exporting countries; in other words, the real exchange rates of the Bolivian boliviano, Mexican peso, and Norwegian krone tend to appreciate against the US dollar.

Thalassinos and Politis (2012) also assess the relationship between the US dollar exchange rate and oil prices and conclude that the USD real exchange rate is negatively correlated with oil prices in the long run. Novorny (2012) also documents the negative relationship between Brent crude oil prices and the US dollar exchange rate. Uddin et al. (2014) investigate the relationship between real oil prices and the Japanese real exchange rate, using wavelet analysis; they conclude the influential role oil prices play on real exchange rate. Al Rasasi and Yilmaz (2016) observe the depreciation of the Turkish exchange rate against the US dollar due to oil price fluctuations. Lastly, Al Rasasi (2017) explores the how changes in oil prices impact nominal effective exchange rate of GCC economies and conclude the influential role of oil shocks on the movements of exchange rates.

\section{Data}

The employed dataset consists of monthly observations spanning from January 1980 to July 2014 for the G7 countries Canada, France, Germany, Italy, Japan, the UK, and the US. G7 countries are the wealthiest countries, and their economies represent more than $50 \%$ of net global income. The dataset is obtained from various sources and consists of real effective exchange rate, policy interest rate, the US crude oil imported acquisition cost by refiners as a measure of oil prices, global crude oil production, and the global industrial production index.

Real exchange rate and policy interest rate data were obtained from the International Financial Statistics database of the International Monetary Fund (IMF). The global industrial production index was downloaded from the Organization for Economic Co-operation and Development (OECD) database. The global crude oil production data was obtained from the US Energy Information Administration. We obtained oil prices from the US Energy Information Administration. The reader should note that we convert oil prices to domestic prices and that we express all variables, except policy interest rate, in logarithm form.

\section{Empirical Methodology and Results}

\subsection{Unit Root Tests}

It is common procedure in empirical analysis to investigate the stochastic properties of the series considered in our models by analyzing their order of integration. To do so, we employ various standard unit root tests. We apply the Augmented Dickey-Fuller (1979), "ADF" test, the Phillips Perron (1988), "PP" test, and the Kwiatkowski et al. (1992), "KPSS" test. The obtained results of these tests confirm the non-stationarity of the data in their levels and the stationarity when the first differences of the data are taken. Detailed results are available upon request from the author.

\subsection{The Structural Vector Autoregressive (SVAR) Model}

To examine the response of real effective exchange rate to oil supply and demand shocks, we follow the procedure of Kilian (2009). Yet, we differ from Kilian in three areas. First, we use the global industrial production index, capturing the demand for all industrial commodities, instead of using the real economic activity index that Kilian developed based on the demand for six industrial commodities. Second, we ensure the 
stationarity of variables in our model. Lastly, Kilian assigns 24 lags in his SVAR model, whereas we rely on the Akaike information criteria (AIC) to determine the appropriate lag length, which is 3 lags, for our SVAR model.

To start the analysis, we estimate the following reduced-form VAR model:

$$
Z_{t}=\alpha+\sum_{i=1}^{k} \mathrm{~A}_{i} \mathrm{Z}_{t-i}+e_{t}
$$

where $Z_{t}=(\operatorname{Prod}, G I P, O i l, R E E R)^{\prime}$ is a $(4 \times 1)$ vector consisting of the percent change in global crude oil production "Prod", the percent change in global industrial production "GIP", the percent change in real oil price "Oil", and the percent change in real effective exchange rate "REER" respectively, according to the given order. The lag length $k$ was chosen based on the AIC criteria, and the vector of reduced-form residuals $e_{t}=\left(e_{\text {prod }}, e_{G I P}, e_{o i l} e_{R E E R}\right)^{\prime}$ is uncorrelated with variables in the period $t-1$ or earlier.

By assuming that the reduced-form residuals, $e_{t}$, are decomposed into structural shocks based on:

$$
e_{t}=A_{0}^{-1} \varepsilon_{t}
$$

Then, we can rewrite equation (2) in terms of the structural shocks to the crude oil market, if we pre-multiply equation (1) by $A_{0}$ to obtain the following equation:

$$
A_{0} Z_{t}=\alpha+\sum_{i=1}^{k} \mathrm{~A}_{i} \mathrm{Z}_{t-i}+\varepsilon_{t}
$$

Thenceforward, we apply a recursive identification scheme, as in Kilian (2009), to identify the structural VAR model as follows:

$$
e_{t}=\left[\begin{array}{c}
e_{\text {Prod }_{t}} \\
e_{G I P_{t}} \\
e_{\text {Oilt }} \\
e_{\text {REE }}
\end{array}\right]=\left[\begin{array}{llll}
a_{11} & 0 & 0 & 0 \\
a_{21} a_{22} & 0 & 0 \\
a_{31} a_{32} a_{33} & 0 \\
a_{41} a_{42} & a_{43} & a_{44}
\end{array}\right]\left[\begin{array}{c}
\varepsilon_{t}^{\text {Sup }} \\
\varepsilon_{t}^{A D} \\
\varepsilon_{t}^{D} \\
\varepsilon_{t}^{R E E R}
\end{array}\right]
$$

where $\varepsilon_{t}^{\text {Sup }}$ is the oil supply shocks, $\varepsilon_{t}^{A D}$ denotes the aggregate demand shocks, $\varepsilon_{t}^{D}$ denotes the oil-specific demand shock, and $\varepsilon_{t}^{R E E R}$ denotes real exchange rate shocks. Based on equation (4), we have four identification assumptions. Firstly, oil supply does not respond contemporaneously to aggregate demand, oil-specific demand shocks, and real exchange rate shocks within the month, due to the uncertainty of the state of the oil market and the high costs associated with oil production. Secondly, global oil demand responds contemporaneously only to innovations in the oil supply, but not to innovations in the price of oil and exchange rate. Thirdly, the price of oil responds to changes in global demand for oil and changes in the oil supply. This, in turn, agrees with the law of supply and demand, in which the variation in price of a certain commodity depends on the variation in supply and demand of the same commodity. Fourthly, the real exchange rate is assumed to respond contemporaneously to all oil supply and demand shocks.

\subsection{Impulse Response Function Analysis}

Now, to understand the dynamic response of real exchange rates to structural oil shocks, we compute the cumulative impulse response functions over a 12-month period with $95 \%$ confidence intervals based on the fixed-design wild bootstrap, as described in Goncalves and Kilian (2004), with 1,000 replications.

Figures 2-3 display the impulse responses with 95\% confidence intervals for all countries. Noticeably, the response of real exchange rates to oil price shocks differs based on the underlying source of the oil shock. For the case of the Canadian real exchange rate, we observe that it appreciates with all structural oil shocks, as shown in Figure 2. Specifically, it tends to depreciate after the second month and continues depreciating over the 12-month period due to oil supply shocks. Likewise, it appreciates significantly following an aggregate demand shock, until the third month, then declines. Furthermore, the real exchange rate appears to respond positively to oil-specific demand shocks and continues to swing during the remaining period. 
Canada
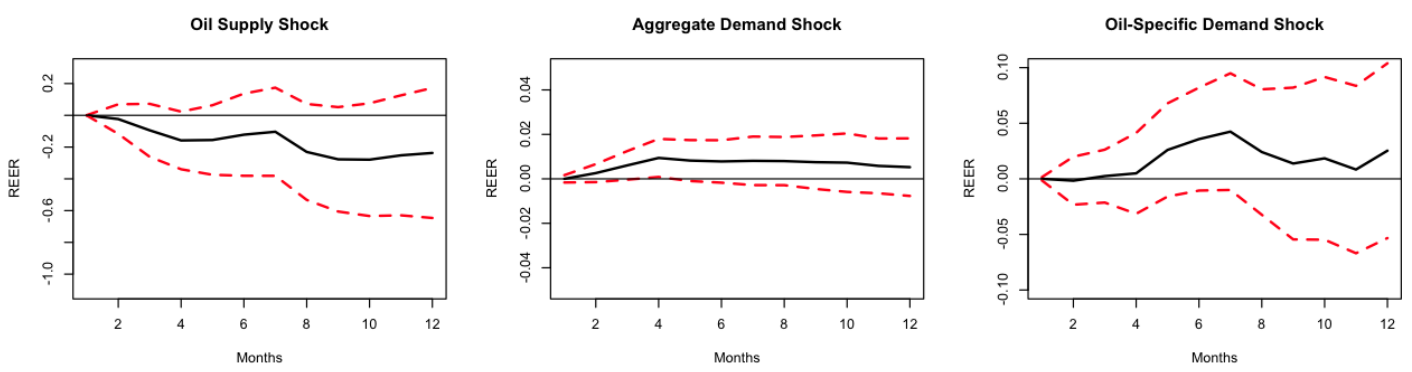

France
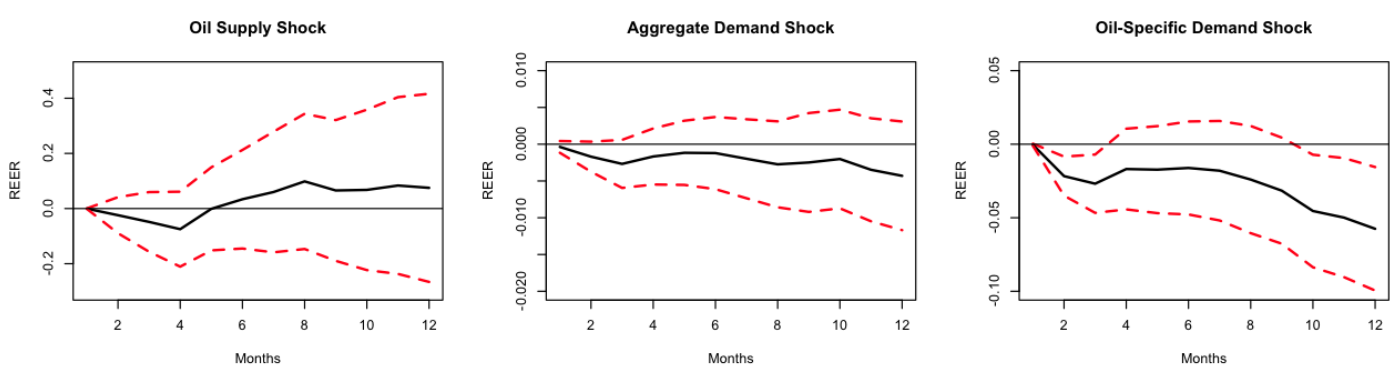

Germany
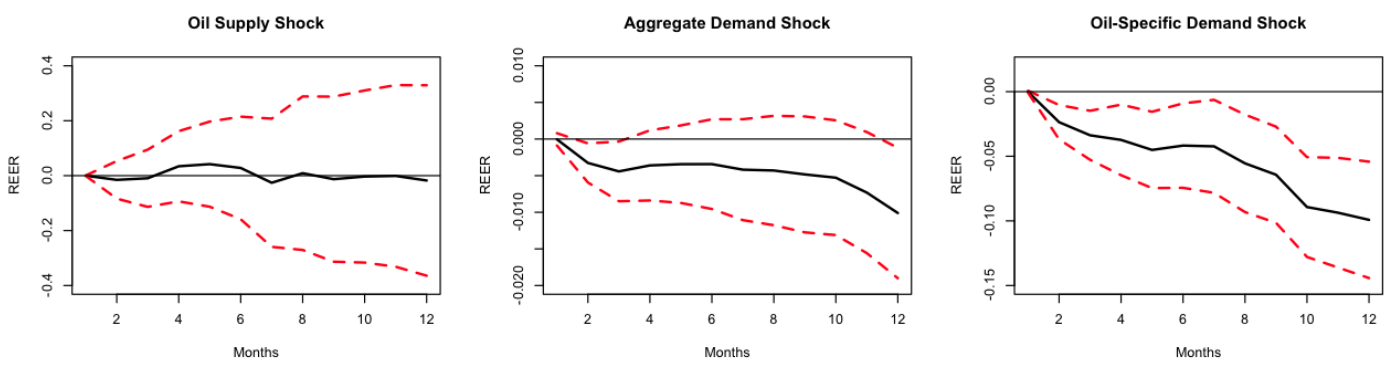

Italy
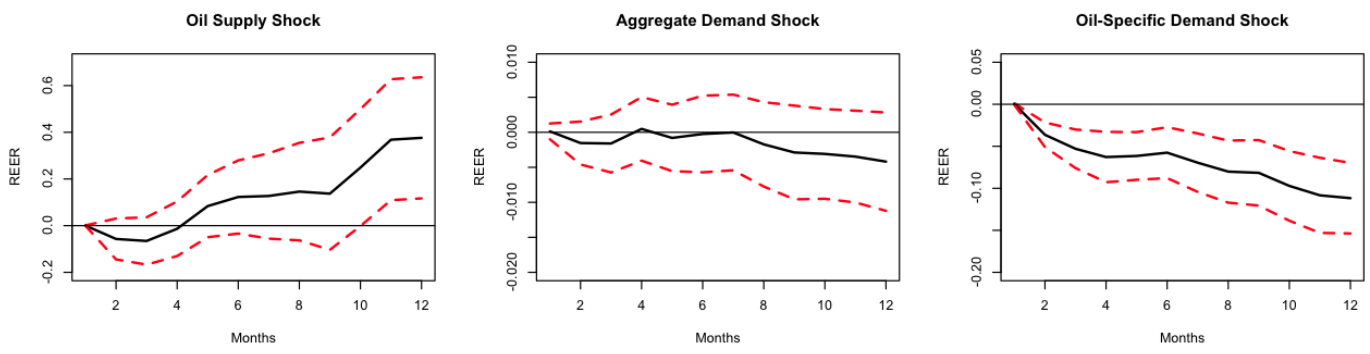

Figure 2. The response of real exchange rate to structural oil price shocks

The plotted impulses for France, Germany, and Italy, as presented in Figure 2, indicate that the decline of real exchange rates is associated with oil supply shocks until the fourth month. However, after the fourth month, real exchange rates switch to appreciation over the remaining period. Analogously, we perceive the significant depreciation of real exchange rates over the time period due to aggregate demand and oil-specific demand shocks. The Japanese real exchange rate, as plotted in Figure 3, tends to respond negatively and significantly only to oil-specific demand shocks over the time horizon. On the other hand, Japanese real exchange rate appreciation is associated with other demand shocks, though insignificant. The US real exchange rate, as shown in Figure 3, seems to respond positively following oil supply and aggregate demand shocks only during the first month, then starts depreciating over the remaining period. The impact of oil-specific demand shocks on the US real exchange rate is negative over the first six months, then the exchange rate starts appreciating until the end of the period.

Concerning the British real exchange rate, the plotted impulses as shown in Figure 3 reveal that oil supply and aggregate demand shocks lead to the appreciation of the real exchange rate immediately, though only aggregate 
demand shocks have a significant impact. As the time horizon increases, we observe the depreciation of the real exchange rate due to oil supply shocks. Correspondingly, oil-specific demand shocks depreciate the British real exchange rates over time. In sum, the structural oil shocks affect the movements of real exchange rates differently across countries. Our findings show that oil supply shocks seem to not have a large impact on some of these countries, which is in line with Kilian (2009)'s argument suggesting the minor effects of oil supply shocks.
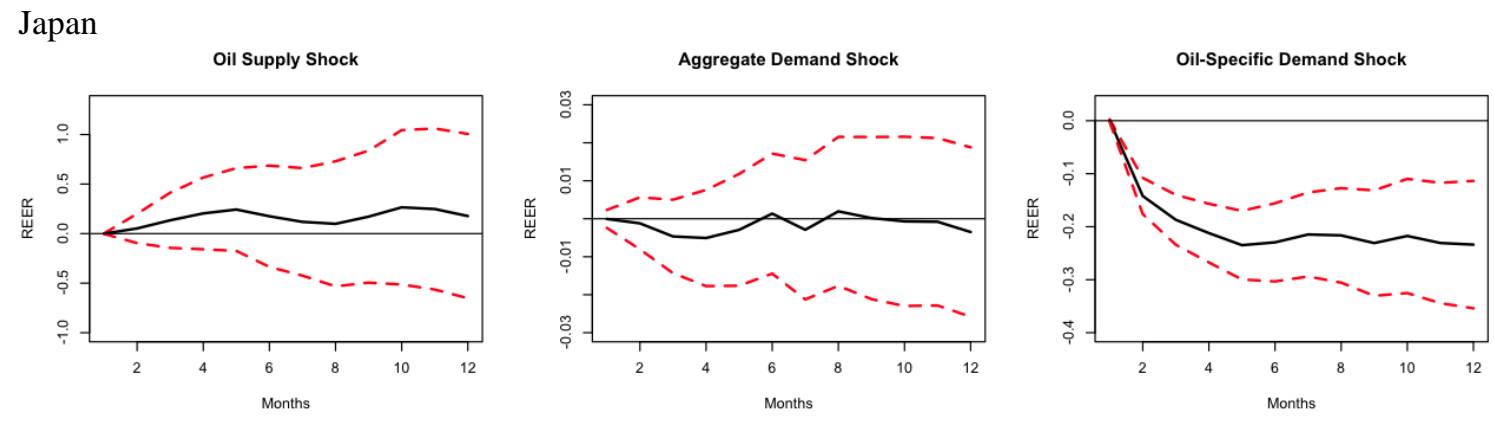

USA
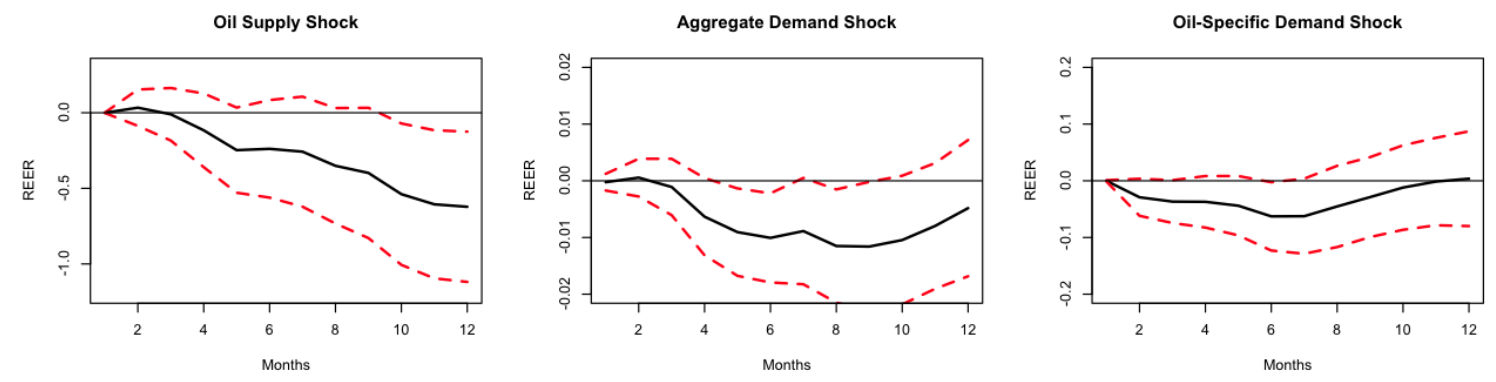

UK
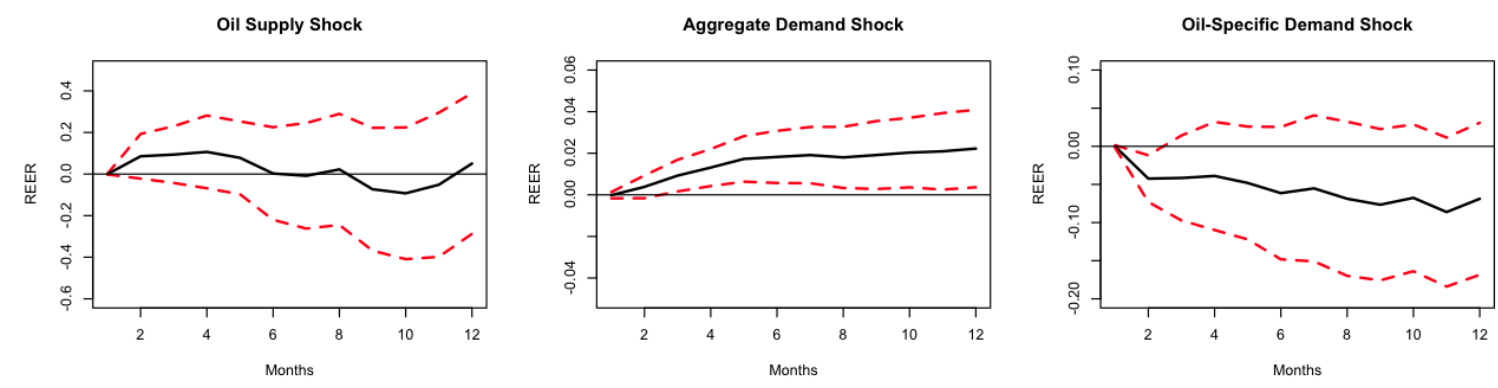

Figure 3. The response of real exchange rate to structural oil price shocks

\subsection{Structural Break Tests}

Now, since we identified the structural oil shocks, it is important to check the stability of the relationship between oil shocks and real exchange rates throughout the period of our analysis. In other words, we must ensure that there has been no structural change in the relationship between the identified structural oil price shocks and real exchange rates during the period of our analysis.

To do so, we employ the Quandt-Andrews unknown breakpoint tests developed by Andrews (1993) and Andrews and Ploberger (1994). These tests estimate the potential structural break dates and do not require any prior information regarding the dates of structural breaks. These tests are Sup F, Ave F, and Exp F, and they test the null hypothesis of no structural change against the alternative of the presence of structural breaks. To obtain these test statistics, we estimate the following model via OLS.

$$
R E E R_{j, t}=\alpha+\sum_{i=1}^{k} \beta_{i} R E E R_{j, t}+\sum_{i=1}^{k} \theta_{i} \varepsilon_{t-i}^{\text {Sup }}+\sum_{i=1}^{k} \delta_{i} \varepsilon_{t-i}^{A D}+\sum_{i=1}^{k} \gamma_{i} \varepsilon_{t-i}^{D}+e_{t}
$$

where $R E E R_{j, t}$ denotes the real effective exchange rate for country $j$ at time period $t$, and $\varepsilon_{t-i}^{S u p}, \varepsilon_{t-i}^{A D}$, $\varepsilon_{t-i}^{D}$ are the identified oil price shocks as oil supply, aggregate demand, and oil-specific demand shocks, respectively. The error term is $e_{t}$, and $\mathrm{k}$ is the lag length that is chosen based on the Akaike information criteria "AIC." 
Table 1 summarizes the results of the structural break tests; the second column is the estimated break date. The remaining columns are the corresponding Ave F, Sup F, and Exp F statistics and their p values in parenthesis. These results indicate the stability of coefficient estimates for all countries, except the UK. Therefore, we test the stability of each coefficient before and after the identified break date for the case of the UK. The results are presented in Table 2 and indicate the stability of the coefficients. The estimated break date, March of 2008, is associated with the 2007-08 financial crisis as documented by some studies, such as Stavárek (2012).

Table 1. Structural break tests

\begin{tabular}{llccc}
\hline & Break Date & Ave F & Sup F & Exp F \\
\hline Canada & August 2007 & 4.58 & 13.02 & 3.10 \\
& & $(0.50)$ & $(0.25)$ & $(0.45)$ \\
France & April 1985 & 2.16 & 5.92 & 1.25 \\
& & $(0.97)$ & $(0.95)$ & $(0.98)$ \\
Germany & July 1988 & 3.67 & 6.44 & 2.04 \\
& & $(0.70)$ & $(0.91)$ & $(0.78)$ \\
Italy & August 1992 & 3.55 & 10.47 & 2.09 \\
& & $(0.73)$ & $(0.48)$ & $(0.77)$ \\
Japan & May 1988 & 3.46 & 6.62 & 1.98 \\
& & $(0.75)$ & $(0.90)$ & $(0.80)$ \\
U.K. & March 2008 & $11.78^{* *}$ & $20.56^{* *}$ & $7.61^{* *}$ \\
& & $(0.01)$ & $(0.02)$ & $(0.01)$ \\
U.S. & April 1985 & 3.14 & 13.05 & 2.97 \\
& & $(0.82)$ & $(0.25)$ & $(0.49)$ \\
\hline
\end{tabular}

Note. ${ }^{* *}$ Indicates the rejection of the null hypothesis at $5 \%$.

Table 2. Structural break tests for the UK

\begin{tabular}{llcccccc}
\hline & Date break & Ave F & P-value & Sup F & P-value & Exp F & P-value \\
\hline Pre-break date & September 1992 & 6.70 & $(0.64)$ & 13.76 & $(0.60)$ & 4.03 & $(0.69)$ \\
Post-break date & February 2009 & 8.45 & $(0.37)$ & 17.97 & $(0.24)$ & 6.12 & $(0.25)$ \\
\hline
\end{tabular}

Since the structural break tests indicate instability between structural oil shocks and the British real exchange rate, we split the UK sample into pre-break and post-break date periods. Panels A and B of Figure 4 show the plotted impulses during the pre-break date period and the post-break date period respectively.

In the pre-break sample, the plotted impulses indicate that the appreciation of the real exchange rate is associated with all structural oil shocks over the time horizon, although insignificant, as shown in Panel A of Figure 4. The appreciation following an aggregate demand shock starts in the first month, and fluctuates over the time horizon. The real exchange rate responds negatively to oil supply shocks during the first month, then starts appreciating after the second month, throughout the remaining period. The impact of oil-specific demand shocks on real exchange rate movements appears to be stable during the first five months, then the real exchange rate starts swinging until the end of the period.

Panel A
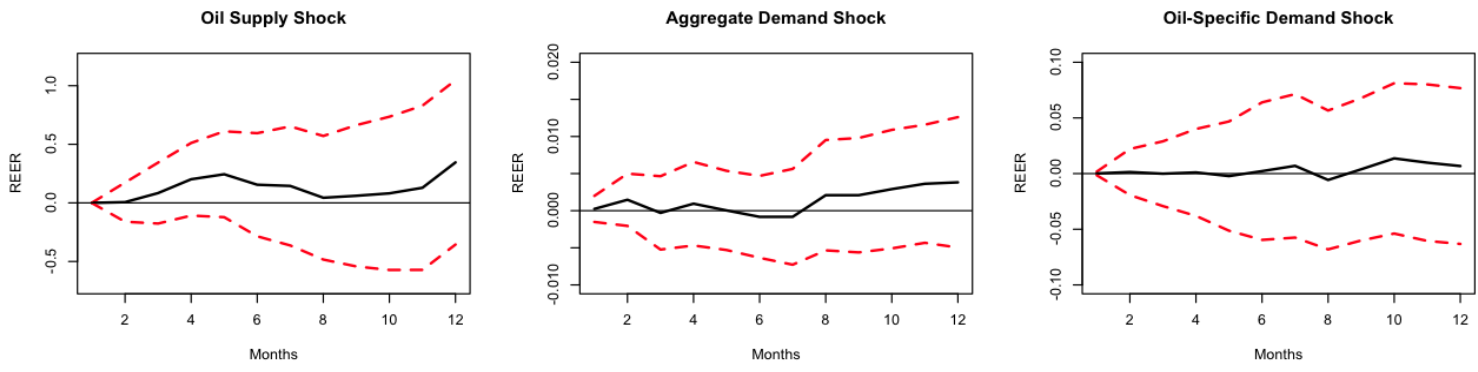
Panel B
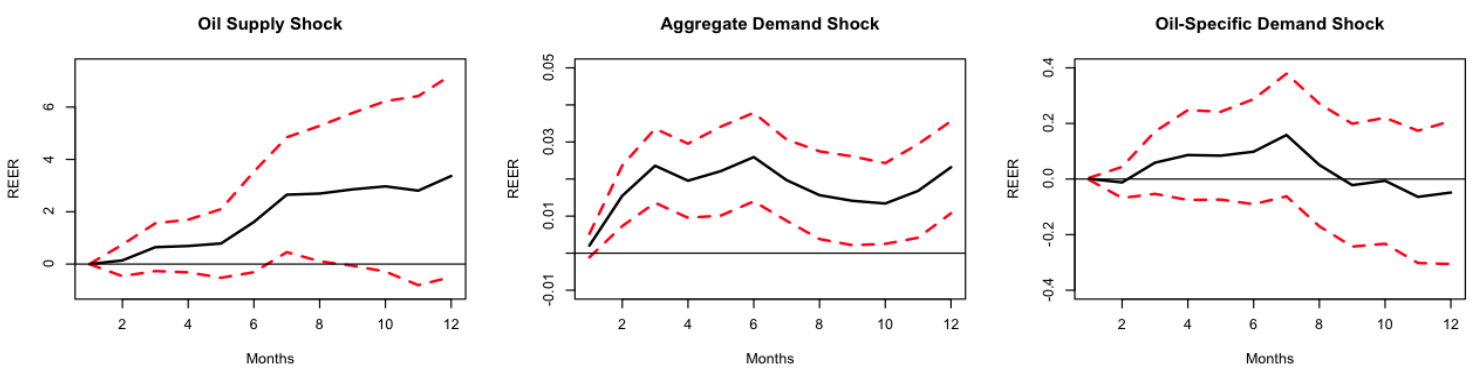

Figure 4. The response of british real exchange rate to structural oil shocks

For the post-break sample, the plotted impulse responses, as shown in Panel B of Figure 4, indicate the significant impact of oil supply and aggregate demand shocks, leading to significant appreciation of the British real exchange rate over the time horizon. However, oil-specific demand shocks have immediate negative impacts on the real exchange rate, and as the time horizon increases, the real exchange rate tends to swing following oil-specific demand shocks, experiencing both appreciation and depreciation points.

Even though the UK became a net oil importer in 2013, we find evidence suggesting the appreciation of the British real exchange rate for both sub-samples. This might be rational for the UK as an oil-exporting country prior to 2013, but not after 2013 as a net importer. A possible explanation for this might be attributed to their high reserve (three billion barrels) of crude oil in 2014, according to the US EIA. It is also worth emphasizing that the UK is a large economy trading with the rest of the world, and its currency is one of the most active trading currencies in international currency markets. These factors increase the demand for the UK's currency. Furthermore, an expectation of appreciation might also be reasonable for the UK after 2013 if we consider the large oil reserve and the discovery of new oil wells in the North Sea in 2014.

\subsection{Forecast Error Variance Decomposition Analysis}

To understand the relative contribution of each structural shock in explaining the movements of real exchange rates, we use the forecast error variance decomposition (FEVD). The FEVD analysis illustrates the relative importance of each structural oil shock and enables us to trace out the effects of a one standard deviation change on real exchange rate movements over time horizons (Tables 3 and 4). The variance decomposition results suggest that the structural oil price shocks are a considerable source of real exchange rate fluctuations over time. In other words, the total contribution of all three oil price shocks on the movements of G7 real exchange rates varies within a range of 0.35 percent and 17.66 percent during the first month, and increases to a range of 3.19 percent and 41.91 percent after 12 months.

The results indicate that oil-supply shocks are the least important factor in explaining the movements of real exchange rates for the Group of Seven countries. In sum, the contribution of oil supply shocks in explaining real exchange rate volatility is between 0.0004 and 11.38 percent after the first month. As the forecasting horizon increases to 12 months, this range only increases to between 0.05 and 7.78 percent.

On the other hand, we find that aggregate demand and oil-specific demand shocks play more important roles in explaining real exchange rate swings over the 12-month time horizon. Aggregate-demand shocks seem to be the second-most important shocks in explaining real exchange rate fluctuations for all countries. In Canada, for instance, aggregate demand shocks explain about 0.58 percent of real exchange rate fluctuations during the first month; as the forecasting horizon increases to six months, we find that aggregate demand shocks explain approximately 1.93 percent of real exchange rate movements. When the forecast horizon moves to 12 months, the role of aggregate demand shocks in illustrating real exchange rate movements appears to be about 2.09 percent. Similar interpretation is applied for other countries.

Table 3. Forecast variance decomposition

\begin{tabular}{lcccccccc}
\hline \multicolumn{9}{c}{ Canada } \\
\hline $\mathrm{H}$ & $\varepsilon_{t}^{\text {Sup }}$ & $\varepsilon_{t}^{A D}$ & $\varepsilon_{t}^{D}$ & Total & $\varepsilon_{t}^{\text {Sup }}$ & $\varepsilon_{t}^{A D}$ & $\varepsilon_{t}^{D}$ & Total \\
\hline 1 & 0.0763 & 0.2620 & 0.0165 & 0.3548 & 0.5936 & 0.7187 & 4.5207 & 5.8330 \\
3 & 0.1152 & 1.3435 & 0.0346 & 1.4933 & 0.6825 & 1.0598 & 4.8988 & 6.6411 \\
6 & 0.1188 & 1.6126 & 1.4377 & 3.1691 & 1.5368 & 1.1566 & 4.8392 & 7.5326 \\
12 & 0.1259 & 1.6278 & 1.4429 & 3.1966 & 1.5414 & 1.1642 & 4.8506 & 7.5562 \\
\hline
\end{tabular}




\begin{tabular}{lcccccccc}
\hline \multicolumn{9}{c}{ Germany } \\
\hline $\mathrm{H}$ & $\varepsilon_{t}^{\text {Sup }}$ & $\varepsilon_{t}^{A D}$ & $\varepsilon_{t}^{D}$ & Total & $\varepsilon_{t}^{\text {Sup }}$ & $\varepsilon_{t}^{A D}$ & $\varepsilon_{t}^{D}$ & Total \\
\hline 1 & 0.2243 & 2.9971 & 4.8870 & 8.1084 & 0.5580 & 0.5785 & 5.2281 & 6.3646 \\
3 & 0.9832 & 3.1984 & 5.1168 & 9.2984 & 0.7625 & 0.9931 & 5.4776 & 7.2332 \\
6 & 1.0706 & 3.3221 & 5.1743 & 9.5670 & 1.0751 & 1.9343 & 5.4431 & 8.4525 \\
12 & 1.0723 & 3.3352 & 5.1777 & 9.5852 & 1.0741 & 2.0856 & 5.4492 & 8.6089 \\
\hline \multicolumn{9}{c}{ Japan } \\
\hline $\mathrm{H}$ & $\varepsilon_{t}^{\text {Sup }}$ & $\varepsilon_{t}^{\text {AD }}$ & Total & $\varepsilon_{t}^{\text {Sup }}$ & $\varepsilon_{t}^{A D}$ & USA & $\varepsilon_{t}^{D}$ & Total \\
\hline 1 & 0.0036 & 0.0615 & 17.6005 & 17.6656 & 0.0004 & 0.2134 & 1.8932 & 2.1070 \\
3 & 0.0242 & 0.4647 & 17.9699 & 18.4588 & 0.5883 & 1.1815 & 1.9841 & 3.7539 \\
6 & 0.0484 & 0.6309 & 17.8910 & 18.5703 & 0.9634 & 1.3008 & 2.5808 & 4.8450 \\
12 & 0.0497 & 0.6847 & 17.8916 & 18.6260 & 0.9723 & 1.3801 & 2.5858 & 4.9382 \\
\hline
\end{tabular}

Note. the reported numbers are percentage rate.

Table 4. Forecast variance decomposition for the UK

\begin{tabular}{lcccc}
\hline \multicolumn{5}{c}{ Full sample } \\
\hline $\mathrm{H}$ & $\varepsilon_{t}^{\text {Sup }}$ & $\varepsilon_{t}^{A D}$ & $\varepsilon_{t}^{D}$ & Total \\
\hline 1 & 0.7659 & 0.3838 & 3.5833 & 4.733 \\
3 & 0.7270 & 2.7204 & 3.2736 & 6.721 \\
6 & 0.8152 & 3.7442 & 3.3446 & 7.904 \\
12 & 0.8148 & 4.1035 & 3.3704 & 8.288 \\
\hline \multicolumn{5}{c}{ Pre-break sample } \\
\hline $\mathrm{H}$ & $\varepsilon_{t}^{\text {Sup }}$ & $\varepsilon_{t}^{A D}$ & $\varepsilon_{t}^{D}$ & Total \\
\hline 1 & 0.2952 & 0.4511 & 6.9727 & 7.719 \\
3 & 0.3868 & 2.4388 & 7.6654 & 10.49 \\
6 & 0.4881 & 2.9810 & 8.5904 & 12.059 \\
12 & 0.5017 & 3.1081 & 8.5756 & 12.185 \\
\hline \multicolumn{5}{c}{ Post-break sample } \\
\\
\hline 1 & $\varepsilon_{t}^{\text {Sup }}$ & $\varepsilon_{t}^{A D}$ & $\varepsilon_{t}^{D}$ & Total \\
\hline 3 & 11.3783 & 2.8526 & 1.31892 & 15.5498 \\
6 & 8.52351 & 9.9343 & 18.7219 & 37.1797 \\
12 & 7.83668 & 13.220 & 20.0623 & 41.1189 \\
\hline
\end{tabular}

Note. the reported numbers are percentage rate.

Oil-specific demand shocks are the most important shocks in explaining the movements of real exchange rates, as the forecast error variance decomposition results show for all countries. The range of the impact of oil-specific demand shocks in explaining the movements of real exchange rates for all countries lies in the range of 1.32 and 17.60 percent during the first month of the forecasting horizon. After 12 months, we find that the contribution of oil-specific demand shocks tends be very important with a range between 3.37 and 19.92 percent. For illustration, oil-specific demand shocks explain about 17.60 percent of the Japanese real exchange rate variations during the first month; likewise, as the forecast horizon increases to 12 months, we find that oil-specific demand shocks explain approximately 17.89 percent of Japanese real exchange rate variations. The same analysis applies for other countries.

Overall, the conclusion inferred from the forecast error variance decomposition results is confirmed by the dominant view from the impulse response function analysis. In other words, structural oil shocks play an essential role in explaining the variations in real exchange rates.

\subsection{The Role of Monetary Policy}

An extensive number of studies discuss the essential role of monetary policy in responding to the consequences of real exchange rate and oil price shocks. Most of the existing literature attempts to answer the following questions: first, does monetary policy react to oil price shocks? Second, does monetary policy react to real exchange rate shocks? Answering these questions is not new in the literature; however, the provided answers regarding these equations vary. Therefore, we attempt to address these questions to see whether our answers agree with the existing studies or not. Regarding the first question, there is an existing debate about the effectiveness of monetary policy in reducing the consequences of oil price shocks. Bernanke et al. (1997) argue 
that much of the recessionary consequences (i.e. lower output and lower employment rate) are due to the upward movements of the interest rate resulting from the Fed's endogenous response to higher inflation induced by oil shocks. However, Hamilton and Herrera (2004) challenge the conclusion of Bernanke et al. (1997) and alleviate the responsibility of monetary policy in the transmission of oil price shocks to economic activities. In addition, they argue that the model of Bernanke et al. (1997) is misspecified and underestimates the direct consequences of oil price shocks on real output. Hamilton and Herrera also attribute the misleading perception of the monetary policy driven by the Federal Reserve to Bernanke et al. (1997). Additional evidence provided by Bachmeier (2008) shows that monetary policy does not play a role in the transmission of oil shocks to the economy. Likewise, Kilian and Lewis (2011) re-examine the findings of Bernanke et al. (1997) with additional data and econometric techniques and find that a systematic monetary policy does not react to oil shocks after 1987. Kilian and Lewis (2011) also explore the response of monetary policy to differential oil price shocks developed by Kilian (2009), and find that monetary policy tends to respond positively with statistical significance to aggregate demand shocks and oil-specific demand shocks by raising the interest rate. Their evidence also shows that monetary policy reacts negatively to oil supply shocks, but it is statistically insignificant.

On the other hand, there are several studies attempting to answer the second question. Because changes in real exchange rates are considered as an indicator for monetary policy when there is uncertainty about the exchange rate, many studies explore whether monetary policy responds to real exchange rate variability or not. For instance, Clarida et al. (1998) find evidence showing that in Japan and some European countries, monetary policy reacts to changes in exchange rates. Likewise, Lubik and Schorfheide (2007) show that the central banks of Canada and the UK respond to exchange rate variations, while the central banks of Australia and New Zealand do not. Similarly, Dong (2008) finds that monetary authorities in Australia, Canada, and the UK respond to exchange rate fluctuations, whereas the monetary authority in New Zealand does not. Alstadheim et al. (2013) show that, in Canada, Sweden, and the UK, the response of monetary policy to exchange rates varies over time. Additionally, Glick and Leduc (2013) document that the US monetary policy reacts to changes in the dollar exchange rate. Bjørnland and Halvorsen (2014) examine whether monetary policy responds to exchange rate fluctuations and find evidence showing that monetary policy reacts to changes in exchange rates only in Canada, Sweden, Norway, and New Zealand, but not in Australia and the UK (Note 1).

Now before going further in evaluating the response of monetary policy to exchange rate shocks alongside oil shocks, we need to check the stationarity of the interest rate data based on the unit root tests described in subsection (4.1). The obtained results of these tests suggest that interest rate data are nonstationary in levels, but stationary in the first difference. Then, to explore whether the G7 central banks respond to the identified oil price and real exchange rate shocks, we regress the policy interest rate on oil and exchange rate shocks, as shown in equation (6).

$$
R_{j, t}=\beta_{0}+\beta_{1} \varepsilon_{t}^{\text {Sup }}+\beta_{2} \varepsilon_{t}^{A D}+\beta_{3} \varepsilon_{t}^{D}+\beta_{4} \varepsilon_{t}^{R E E R}+e_{t}
$$

where $R_{j, t}$ denotes the change in the interest rate for country $\mathrm{j}$ at time t. Also, note that $\varepsilon_{t-i}^{\text {Sup }}, \varepsilon_{t-i}^{A D}, \varepsilon_{t-i}^{D}$ denotes the identified oil supply shock, aggregate demand shock, and oil-specific demand shock for country $\mathrm{j}$ at time $t$, respectively. The $\varepsilon_{t}^{R E E R}$ variable denotes the identified real exchange rate shock for country $\mathrm{j}$ at time $\mathrm{t}$, and $e_{t}$ is the error term.

Table 5. Monetary policy responses to structural shocks

\begin{tabular}{lcccc}
\hline & $\widehat{\beta_{1}}$ & $\widehat{\beta_{2}}$ & $\widehat{\beta_{3}}$ & $\widehat{\beta_{4}}$ \\
\hline Canada & -5.09 & 0.09 & -0.35 & -2.99 \\
& $(-1.17)$ & $(1.39)$ & $(-0.52)$ & $(-1.23)$ \\
France & -1.98 & 0.06 & 0.11 & 2.79 \\
& $(-0.66)$ & $(1.05)$ & $(0.48)$ & $(0.64)$ \\
Germany & -0.56 & 0.03 & 0.13 & -0.39 \\
& $(-0.58)$ & $(0.67)$ & $(0.84)$ & $(-0.26)$ \\
Italy & -1.68 & 0.06 & -0.32 & $-4.11^{*}$ \\
& $(-0.74)$ & $(1.34)$ & $(-0.84)$ & $(-1.98)$ \\
Japan & -1.87 & $0.19 * *$ & $0.61 * *$ & $-2.17^{* *}$ \\
& $(-1.03)$ & $(3.91)$ & $(3.66)$ & $(-2.06)$ \\
U.S. & -2.36 & $0.16^{* *}$ & $0.31 * * *$ & $7.28^{* *}$ \\
& $(-1.21)$ & $(4.16)$ & $(1.61)$ & $(3.33)$ \\
\hline
\end{tabular}

Note. Numbers in parenthesis are t-values based on Newey-West (1987) standard errors.

$*, * *, * * *$ Indicate the significance levels at $1 \%, 5 \%$, and $10 \%$ respectively. 
Table 6. British monetary policy responses

\begin{tabular}{lcccc}
\hline & $\widehat{\beta_{1}}$ & $\widehat{\beta_{2}}$ & $\widehat{\beta_{3}}$ & $\widehat{\beta_{4}}$ \\
\hline Pre-break date & -3.09 & $0.38^{* *}$ & 0.16 & 2.58 \\
& $(-1.54)$ & $(5.58)$ & $(0.67)$ & $(1.58)$ \\
Post-break date & 0.15 & $0.09^{* *}$ & $0.67^{* *}$ & $1.98^{* * *}$ \\
& $(0.12)$ & $(3.01)$ & $(3.22)$ & $(1.61)$ \\
\hline
\end{tabular}

Note. Numbers in parenthesis are t-values based on Newey-West (1987) standard errors.

$*, * *, * * *$ Indicate the significance levels at $1 \%, 5 \%$, and $10 \%$ respectively.

Tables 5 and 6 present the estimated parameters of oil price and real exchange rate shocks as given in equation (6). The response of policy interest rate to oil supply shocks seems to be negative in all cases, but it is statistically insignificant. On the other hand, the policy interest rate tends to respond positively and statistically significantly to aggregate demand and oil-specific demand shocks for Japan, the UK, and the US.

This finding agrees with Kilian and Lewis (2011), who document that raising the interest rate in the US in response to a positive aggregate demand shock is consistent with the implemented monetary policy before the oil price shock of 1973. They also add that the implemented monetary policy leading to cut the interest rate because of an oil supply shock is consistent with the Federal Reserve's view that surges in oil prices are adverse aggregate demand shocks (Note 2).

In relation to the response of monetary policy to exchange rate volatility, the estimated parameter of real exchange rate shocks $\left(\beta_{4}\right)$ indicates that only the monetary authorities represented by the central banks of Italy, Japan, the UK, and the US respond significantly to real exchange rate fluctuations. This, in turn, indicates that the monetary policy has been, to some extent, directed towards stabilizing the nominal exchange rates for these countries. However, we find no evidence of monetary policy in other countries responding to exchange rate fluctuations. This might be due to the absence of policy coordination among G7 countries regarding exchange rates. In line with this notion, Fratzscher (2009) documents that G7 countries played essential roles in managing their exchange rates in the early years, since the breakdown of the Bretton Woods Fixed Exchange Rate System. Fratzscher adds that their role in policy coordination regarding the movements of exchange rates, however, became weaker after 1995 .

A plausible explanation for the weak role of monetary policy in responding to exchange rate movements in these countries is the use of alternative instruments by policymakers. One of the alternative instruments implemented by monetary authorities is the central bank intervention in the currency market for stabilization purposes. For example, the Bank of Japan has tended to intervene in the currency market in recent years to stabilize its exchange rate, as stated by Archer (2005). Correspondingly, Dupuy (2008) argues that some of the Euro zone major trading partners, such as Japan and the US, have tended to manipulate their currency to low levels to stimulate their exports and sustainable growth.

\section{Implications of Results}

Structural oil price shocks play an essential role in capturing the movements of real exchange rates, though the impact may vary depending on the underlying source of these shocks. Thus, our empirical results have several important implications on the economy that should be considered by economists, traders, financial and market analysts, and policymakers.

Oil supply, aggregate demand, and oil-specific demand shocks may lead to the appreciation or depreciation of real exchange rates, as discussed in the previous sections. Consequently, it is important to understand the implications of real exchange rates' movements. The depreciation of real exchange rates has positive and negative impacts on the economy. By exploring some of the negative consequences, we find that a weak exchange rate value yields a lower international purchasing power for the citizens of G7 countries. Additionally, the depreciation of real exchange rates indicates lower returns on G7 assets, and this in turn discourages foreign investors from holding G7 assets.

In contrast, the depreciation of real exchange rates may become a key engine to stimulate economic activity via higher prices of foreign goods relative to domestic goods. This, in turn, raises the international competitiveness of domestic goods, leading to a reallocation from spending on foreign goods to domestic goods. This would be reflected not only in a reduction in the trade deficit, but also in a reduction in the unemployment rate to meet the strong demand for exported goods in international markets.

The empirical evidence indicates that monetary policy in four countries of the G7 does not react to real exchange 
rate fluctuations. This suggests the essential role of policy coordination between G7 countries to stabilize real exchange rates. Direct market intervention in the foreign exchange market would be a useful tool to stabilize exchange rate movements by monetary authorities of each of the $\mathrm{G} 7$ countries.

To prevent such negative implications of exchange rate movements on the world economy, the International Monetary Fund (IMF) and the World Trade Organization (WTO) could implement some policies. Because some countries intend to undervalue their currencies to stimulate their economies via raising net exports, the IMF could identify and evaluate the implemented monetary policies by central banks. The WTO could set some rules to prevent trade competition as suggested by Dupuy (2008). It would also be necessary for these policies to correlate with the objectives of the IMF and WTO.

\section{Conclusion}

The main objective of this paper is to assess the essential role of different oil price shocks on the variation of G7 real exchange rates. To achieve this objective, we derive the oil supply and demand shocks following Kilian (2009) and investigate the response of real exchange rates to these shocks using monthly data spanning from January 1980 to July 2014.

We find evidence suggesting the essential role of oil structural shocks in capturing the movements of real exchange rates. We observe that the response of the exchange rate tends to vary depending on the underlying source of the oil shock, whether oil supply or demand shocks. Importantly, structural break tests we employed indicate the stability of the relationship between real exchange rates and the identified structural oil shocks for all countries except the UK.

Due to the ongoing debate regarding the role of monetary policy in responding to oil price shocks, we explore whether monetary policy responds to oil price shocks or not, and conclude that the monetary authorities of G7 countries do not respond to oil supply shocks, as suggested by Hamilton and Herrera (2004). Conversely, the revealed evidence indicates that only the central banks of Japan, the UK, and US react to demand shocks; this finding is in line with the finding of Lewis and Kilian (2011). Concerning the role of monetary policy in reacting to exchange rate fluctuations, it seems that only the monetary authorities of Italy, Japan, and the US react to changes in real exchange rates. This finding is consistent with the results of Glick and Leduc (2013) and Halvorsen (2014).

\section{References}

Akram, Q. F. (2004). Oil prices and exchange rates: Norwegian evidence. The Econometrics Journal, 7(2), 476-504. https://doi.org/10.1111/j.1368-423X.2004.00140.x

Al Rasasi, M. (2017). Oil prices and GCC exchange rates. Energy Sources, Part B: Economics, Planning, and Policy, 12(7), 344-350. https://doi.org/10.1080/15567249.2015.1132284

Al Rasasi, M., \& Yilmaz, M. (2016). The Effects of Oil Shocks on Turkish Macroeconomic Aggregates. International Journal of Energy Economics and Policy, 6(3), 471-476.

Alstadheim, R., Bjørnland, H. C., \& Maih, J. (2013). Do central banks respond to exchange rate movements? A Markove-Switiching structural investigation. Working Papers 0018, Centre for Applied Macro- and Petroleum economics (CAMP), BI Norwegian Business School.

Amano, R. A., \& Van Norden, S. (1998). Exchange Rates and Oil Prices. Review of International Economics, 6(4), 683-694. https://doi.org/10.1111/1467-9396.00136

Andrews, D. (1993). Tests for parameter instability and structural change with unknown change Point. Econometrica, 61(4), 825-66. https://doi.org/10.2307/2951764

Andrews, D., \& Ploberger, W. (1994). Optimal tests when a nuisance parameter is present only under the Alternative. Econometrica, 62(6), 1383-414. https://doi.org/10.2307/2951753

Archer, D. (2005). Foreign exchange market intervention: methods and tactics. Bank for International Settlements Working Paper No. 24, pp. 40-55.

Bachmeier, L. (2008). Monetary policy and the transmission of oil shocks. Journal of Macroeconomics, 30(4), 1738-1755. https://doi.org/10.1016/j.jmacro.2007.11.002

Backus, D. K., \& Crucini, M. J. (2000). Oil prices and the terms of trade. Journal of International Economics, 50(1), 85-213. https://doi.org/10.1016/S0022-1996(98)00064-6

Basher, S. A., Haug, A. A., \& Sadorsky, P. (2012). Oil Prices, Exchange Rates and Emerging Stock Markets. Energy Economics, 34(1), 227-240. https://doi.org/10.1016/j.eneco.2011.10.005 
Beine, M. (2006). Conditional covariances and direct central bank interventions in the foreign exchange markets. Journal of Banking and Finance, 28(6), 1385-1411. https://doi.org/10.1016/S0378-4266(03)00124-9

Bello, Z. (2013). The association between exchange rates and stock returns. Investment Management and Financial Innovations, 10(3), 40-45.

Bernanke, B., Gertler, M., \& Watson, M. (1997). Systematic Monetary Policy and the Effects of Oil Price Shocks. Brookings Papers on Economic Activity, 1, 91-142. https://doi.org/10.2307/2534702

Bjørnland, H. C., \& Halvorsen, J. I. (2014). How does Monetary Policy Respond to Exchange Rate Movements? New International Evidence. Oxford Bulletin of Economics and Statistics, 76(2), 208-231. https://doi.org/10.1111/obes.12014

Burgess, S. M., \& Knetter, M. M. (1998). An International Comparison of Employment Adjustment to Exchange Rate Fluctuations. Review of International Economics, 6(1), 151-163. https://doi.org/10.1111/1467-9396.00094

Cashin, P., Cespedes, L. F., \& Sahay, R. (2004). Commodity currencies and the real exchange rate. Journal of Development Economics, 75(1), 239-268. https://doi.org/10.1016/j.jdeveco.2003.08.005

Chen, S. S., \& Chen, H. C. (2007). Oil prices and real exchange rates. Energy Economics, 29(3), 390-404. https://doi.org/10.1016/j.eneco.2006.08.003

Clarida, R., Gali, J., \& Gertler, M. (1998). Monetary policy rules in practice: some international evidence. European Economic Review, 42(6), 1033-1067. https://doi.org/10.1016/S0014-2921(98)00016-6

Coudert, V., Mignon, V., \& Penot, A. (2007). Oil price and the dollar. Energy Studies Review, 15(2), 1-18. https://doi.org/10.15173/esr.v15i2.508

Dickey, D. A., \& Fuller, W. A. (1979). Distribution of the estimators of autoregressive time series with a unit root. Journal of the American Statistical Association, 74(366), 427-431. https://doi.org/10.2307/2286348

Dong, W. (2008). Do Central Banks Respond to Exchange Rate Movements? Some New Evidence from Structural Estimation. Discussion Paper, Bank of Canada, Working paper.

Dupuy, M. (2008). The Impact of Exchange Rate Fluctuations on Trade Policy. Briefing Paper, Directorate General External Policies of the Union, European Parliament.

Eichenbaum, M., \& Evans, C. L. (1995). Some Empirical Evidence on the Effects of Shocks to Monetary Policy on Exchange Rates. The Quarterly Journal of Economics, 110(4), 975-1009. https://doi.org/10.2307/2946646

Faust, J., \& Rogers, J. H. (2003). Monetary policy's role in exchange rate behavior. Journal of Monetary Economics, 50(7), 1403-1424. https://doi.org/10.1016/j.jmoneco.2003.08.003

Fratzscher, M. (2009). How successful is the G7 in managing exchange rates? Journal of International Economics, 79(1), 78-88. https://doi.org/10.1016/j.jinteco.2009.06.002

Gali, J., \& Monacelli, T. (2005). Monetary Policy and Exchange Rate Volatility in a Small Open Economy. Review of Economic Studies, 72(252), 707-734. https://doi.org/10.1111/j.1467-937X.2005.00349.x

Glick, R., \& Leduc, S. (2013). Unconventional Monetary Policy and the Dollar. Federal Reserve Bank of San Francisco ECONOMIC LETTER, April 2013.

Goncalves, S., \& Kilian, L. (2004). Bootstrapping Autoregressions with conditional heteroskedasticity of unknown form. Journal of Econometrics, 123(1), 89-120. https://doi.org/10.1016/j.jeconom.2003.10.030

Hamilton, J., \& Herrera, A. (2004). Oil Shocks and Aggregate Macroeconomic Behavior: The Role of Monetary Policy: Comment. Journal of Money, Credit and Banking, 36(2), 265-86. https://doi.org/10.1353/mcb.2004.0012

Harchaoui, T., Tarkhani, F., \& Yuen, T. (2005). The Effects of the Exchange Rate on Investment: Evidence from Canadian Manufacturing Industries. Bank of Canada Working paper 2005-22.

Hausmann, R., Pritchett, L., \& Rodrik, D. (2005). Growth Accelerations. Journal of Economic Growth, 10(4), 303-329. https://doi.org/10.1007/s10887-005-4712-0

Huang, Y., \& Guo, F. (2007). The role of oil price shocks on China' real exchange rate. China Economic Review, 18(4), 403-416. https://doi.org/10.1016/j.chieco.2006.02.003

Jahan-Parvar, M. R., \& Mohammadi, H. (2008). Oil Prices and Real Exchange Rates in Oil-Exporting Countries: 
A Bounds Testing Approach. MPRA Paper with number 13435, University Library of Munich, Germany, pp. $1-14$.

Kilian, L. (2009). Not All Oil Price Shocks Are Alike: Disentangling Demand and Supply Shocks in the Crude Oil Market. American Economic Review, 99(3), 1053-69. https://doi.org/10.1257/aer.99.3.1053

Kilian, L., \& Lewis, L. (2011). Does the Fed Respond to Oil Price Shocks? The Economic Journal, 121(555), 1047-1072. https://doi.org/10.1111/j.1468-0297.2011.02437.x

Kilian, L., \& Park, C. (2009). The Impact of Oil Price Shocks on the U.S. Stock Market. International Economic Review, 50(4), 1267-1287. https://doi.org/10.1111/j.1468-2354.2009.00568.x

Kilian, L., Rebucci, A., \& Spatafora, N. (2009). Oil shocks and external balances. Journal of International Economics, 77(2), 181-194. https://doi.org/10.1016/j.jinteco.2009.01.001

Kwiatkowski, D., Phillips, P. C. B., Schmidt, P., \& Shin, Y. (1992). Testing the Null Hypothesis of Stationarity against the Alternative of a Unit Root. How sure are we that Economic Time Series have a Unit Root? Journal of Econometrics, 54(1-3), 159-178. https://doi.org/10.1016/0304-4076(92)90104-Y

Lubik, T. A., \& Schorfheide, F. (2007). Do central banks respond to exchange rate movements? A structural investigation. Journal of Monetary Economics, 54(4), 1069-1087. https://doi.org/10.1016/j.jmoneco.2006.01.009

Marimoutou, V., Raggad, B., \& Trabelsi, A. (2009). Extreme value theory and value at risk: Application to oil market. Energy Economics, 31(4), 519-530. https://doi.org/10.1016/j.eneco.2009.02.005

Mohammadi., H., \& Jahan-Parvar, M. R. (2012). Oil prices and exchange rates in oil-exporting countries: Evidence from TAR and M-TAR models. Journal of Economics and Finance, 36(3), 766-779. https://doi.org/10.1007/s12197-010-9156-5

Narayan, P. K., Narayan, S., \& Prasad, A. (2008). Understanding the oil-exchange rate nexus for the Fiji islands. Energy Economics, 30(5), 2686-2696. https://doi.org/10.1016/j.eneco.2008.03.003

Newey, W., \& West, K. (1987). A Simple, Positive Semi-definite, Heteroskedasticity and Autocorrelation Consistent Covariance Matrix. Econometrica, 55(3), 703-708. https://doi.org/10.2307/1913610

Novotny, F. (2012). The Link Between the Brent Crude Oil Price and the US Dollar Exchange Rate. Prague Economic Papers, (2), 220-232. https://doi.org/10.18267/j.pep.420

Phillips, P. C. B., \& Perron, P. (1988). Testing for a Unit Root in Time Series Regression. Biometrica, 75(2), 335-346. https://doi.org/10.1093/biomet/75.2.335

Sadegui, M., \& Shavvalpour, S. (2006). Energy risk management and value at risk modelling. Energy Policy, 34(18), 3367-3373. https://doi.org/10.1016/j.enpol.2005.07.004

Sadorsky, P. (2000). The empirical relationship between energy future prices and exchange rates. Energy Economics, 22(2), 253-266. https://doi.org/10.1016/S0140-9883(99)00027-4

Salmon, M., \& Schleicher, C. (2007). Pricing multivariate currency options with copulas. Working Papers. Warwick Business School, Financial Econometrics Research Centre. Retrieved from http://EconPapers.repec.org/RePEc:wbs:wpaper:wp06-21

Stavárek, D. (2012). Exchange Rate Volatility of US Dollar and British Pound during Different Phases of Financial Crisis. In D. Stavárek \& P. Vodová (Eds.), Proceedings of 13th International Conference on Finance and Banking (pp. 379-385). Karviná: Silesian University, School of Business Administration.

Thalassinos, E. J., \& Politis, E. D. (2012). The evaluation of the USD currency and the oil prices: A VAR Analysis. European Research Studies, XIV(2), 137-146.

Uddin, G. S., Tiwari, A. K., Arouri, M., \& Teulon, F. (2014). On the relationship between oil price and exchange rates: A wavelet analysis. IPAG Business School Working Paper Series, 2014-456.

Yousefi, A., \& Wirjanto, T. S. (2004). The empirical role of the exchange rate on the crude-oil price formation. Energy Economics, 26(5), 783-799. https://doi.org/10.1016/j.eneco.2004.06.001

Zettelmeyer, J. (2004). The impact of monetary policy on the exchange rate: Evidence from three small open economies. Journal of Monetary Economics, 51(3), 635-652. https://doi.org/10.1016/j.jmoneco.2003.06.004 


\section{Notes}

Note 1. For further reading see i.e. Eichenbaum and Evans (1995), Faust and Rogers (2003), Zettelmeyer (2004), and Gali and Monacelli (2005).

Note 2. It is also essential to emphasize that since the formation of the European Union in January 1999, the monetary policy of France, Germany, and Italy is implemented by the European central bank.

\section{Copyrights}

Copyright for this article is retained by the author(s), with first publication rights granted to the journal.

This is an open-access article distributed under the terms and conditions of the Creative Commons Attribution license (http://creativecommons.org/licenses/by/4.0/). 